\title{
Water Harvesting and Water Management
}

\section{A Discussion of the Implications of Scale in Artificial Irrigation: the Sri Lankan Example}

\author{
Eva Myrdal
}

\begin{abstract}
The pre-colonial, large-scale, irrigation systems of the dry zone of Sri Lanka have been used as examples of large-scale undertakings with given social consequences of centralisation and state control. A close reading of a given cultural landscape and a focus on chronology give possibilities for an alternative approach, one in which artificial irrigation does not have an independent role. The starting point for the discussion is the archaeologically comparatively well-explored uplands of the capital city Sigiriya, which dates to the $5^{\text {th }}$ century AD.
\end{abstract}

Eva Myrdal, Museion, Gothenburg University, Box 111, SE-405 30 Göteborg, Sweden.

Key words: Sri Lanka, irrigation, rain-fed, supportive capacity, colonial warfare, village perspectives, comparative studies

\section{BACKGROUND}

In Sri Lanka there were in the mid-1980s 25000 minor irrigation schemes, watering less than 40 ha each. Many of these systems were reclamation schemes (Wijesuriya \& Kamaladasa 1988:92f). In the study area, which is presented below, this is the case for almost all of the documented village tanks. The villagers using the water of these renovated structures referred their initial time of construction to "the days of the ancient kings" or "when all other tanks were built", or they simply stated that they didn't know when they were built (Myrdal-Runebjer 1996:93f).

From what is known today, the present land-use pattern in the study area was established during three main periods of renovation. During the $19^{\text {th }}$ century "the ancestor" or a named founder of the present village repaired a bund of small size. No governmental aid was given, but there are examples where the villagers paid professional tank-menders "from India" to do the work. In one case it is said that the labourers were paid in kind with kurakkan (finger millet) (Myrdal-Runebjer 1996:94ff). The British civil servant levers states in 1899 that before 1874 no governmental assistance was given to renovation projects in the North Central Province. The work was organised by the villagers on their own, generally employing professional Tamil tank-menders for the earth-moving work (Ievers 1899:143). From the same area an Assistant Government Agent reports in 1869 
and 1870 that a "class of professional tank-menders, called kulan kaddies, who come from Jaffna and India" were employed by the villagers to renovate small tanks on a contract basis (Ievers 1899:144f). Ievers states that this group was also employed in the subsequent the restoration of larger structures (levers 1899:144). During the $1930 \mathrm{~s}, 1950 \mathrm{~s}$ and 1960s tanks were improved for the first time with government assistance in the study area (as remembered

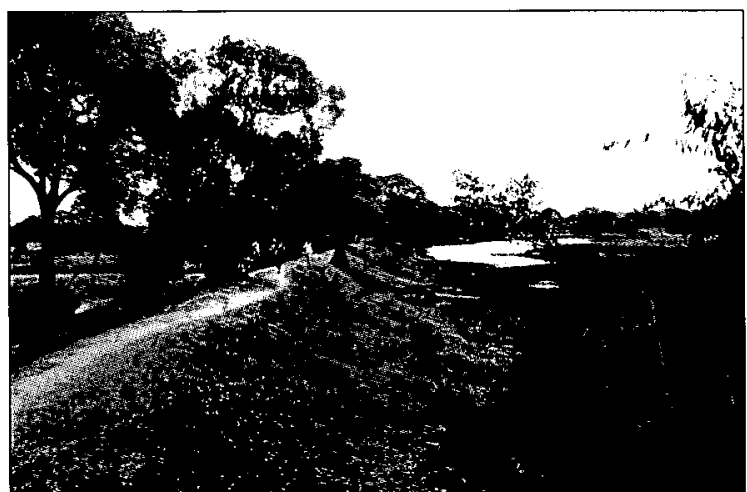

Fig. 1. The village tank Pahala Talkote väva in early September at the end of the dry season. The almost dry tankbed to the right. Photo by the author.

by the villagers). Bunds were made longer, higher and broader; sluices of the katasorovva type (see Fig. 2) and one key-sluice and permanent spillways were constructed; field canals were enlarged, and the irrigation acreage was in several cases expanded (Myrdal-Runebjer 1996:95). In the late 1970s two tanks were subsequently linked to the Mahaveli irrigation system through Sigiri Oya (previously a seasonal stream). Two new sluices were constructed, new fields were laid out, and the cultivation season was prolonged. It was not within the capacity of the villagers to decide on this additional water supply, however. The opportunities for obtaining a yearly irrigated crop are very different for on the one hand the cultivators under these two tanks and on the other hand those under the remaining rain-fed tanks (Myrdal-Runebjer 1996:95).

Structures such as these have not been studied archaeologically, but they have been used as a settlement model for the pre-colonial, village-based irrigation. This model was presented by the Sri Lankan scholar Gunawardana as a "one tank-one village" pattern based on a combination of swidden and wet-rice cultivation (Gunawardana 1971, 1978, and 1982).

Much more spectacular structures have drawn the attention of the scholarly community: there are pre-colonial, earthen, reservoir embankments up to $14 \mathrm{~km}$ long and more than $12 \mathrm{~m}$ high, and there are ancient transbasin canals up to 80 $\mathrm{km}$ long traversing the almost level plain. There is one such reservoir (Parakrama Samudra) which, in its current restored and smaller state, is capable of storing 98.6 million $\mathrm{m} 3$ of water and irrigating an area of 7365.5 ha (Nicholas 1973[1955]:70). Based on literary sources (mainly epigraphical material and Buddhist chronicles) the construction of these large-scale systems has been referred to the period between the $1^{\text {st }}-3^{\text {rd }}$ and $13^{\text {th }}$ centuries AD. Only two reservoirs, the Maduru Oya reservoir and Sigiri Mahaväva, have been dated by ${ }^{14} \mathrm{C}$ and $\mathrm{TL}$ respectively (Abeyratne 1990; Deraniyagala 2, 1992:732-f; Myrdal-Runebjer 1996:128-133). The results do not contradict the general picture. 


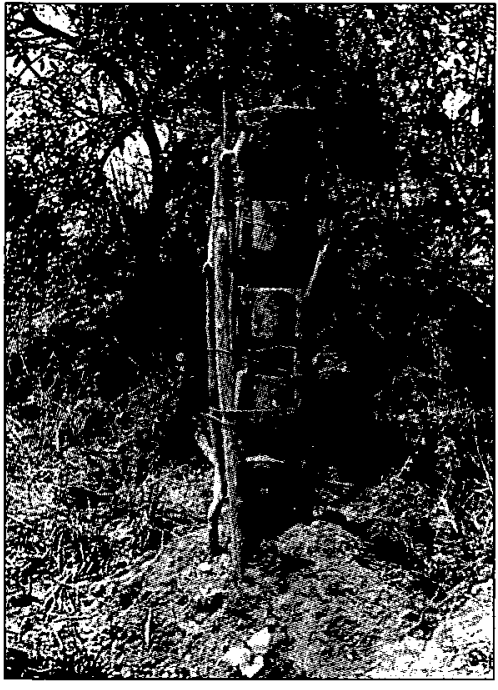

Fig. 2. A village tank sluice (katasorovva) built in mid-October in the Pidurangala Temple tank. Photo by the author.

Obviously structures such as Parakrama Samudra have to be taken into consideration when discussing the Sri Lankan development during the first millennium AD. They have a production potential that is unthinkable in, for example, a Swedish first millennium context (see below). One large reservoir to the north-west of the study area, Kalaväva-Balaluväva, might have had a capacity to produce 3.16 million $\mathrm{kg}$ of paddy per maha-season (the main cultivation season during the north-east monsoon) each year during 700 years $\left(5^{\text {th }}\right.$ to $12^{\text {th }}$ century AD), that is, a total of 2212 million $\mathrm{kg}$ of paddy. A second dry-season crop would not quite double the amount, as the water duty (how large a volume of water that has to be applied during one season/ha) is higher and the available water may be less. Given, say, only half of the wetseason amount, two harvests per year would in any case raise this figure to 3318 million $\mathrm{kg}$ of paddy during the reservoir's precolonial period of operation (Myrdal-Runebjer 1996:160-161). This is combined with a minimum amount of labour to be invested in relation to the structure as such, once the system is completed and if no major breaches occur. Thus, once built the reservoirs will have long-term, supportive effects for the given area (see, e.g., Gunawardana 1982). Wet-rice cultivation in itself, on the other hand, requires a concentrated amount of labour investment during the peak season of water management, harvesting and threshing. This is in contrast to, for example, polyculture swidden cultivation (i.e., several different types of millet, vegetables and root crops are grown mixed together over the swidden field) with its dispersed harvesting season.

This said, we should also note that "irrigation" is not a monolithic feature; there are differences in the scale and supportive capacity and in how the work is organised. The scale of water management organised by the community itself is known to vary through time and in space. In other parts of South Asia there are examples from modern times of "transvillage" irrigation systems that have operated without any organisational control from outside the relevant communities. The river-diversion and canal-irrigation system of the Rajapur island in western Nepal, covering over 14000 ha of irrigated land, was developed during the $19^{\text {th }}$ century - that is, initiated, constructed, maintained and managed - by the users (Cederroth 1995). The Dusi-Mamanadur tank in Tamil Nadu, India, is another example of present-day, community-level decisions on maintenance and water management taken by representatives of, in this case, 18 villages (Chambers 1979:352). The crucial issue seems to be to organise co-operation between the communities that 


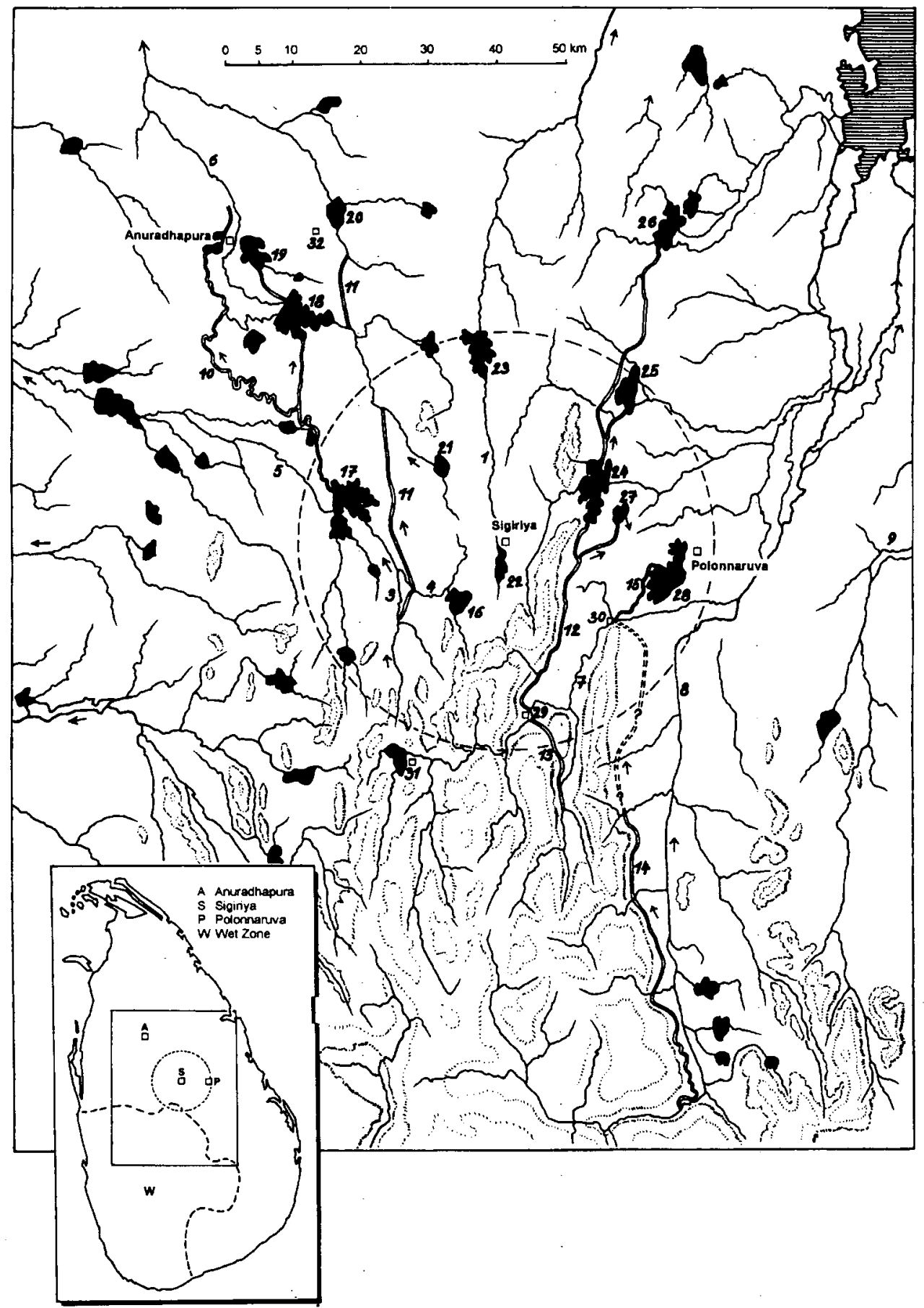

Fig. 3. The large-scale irrigation landscape to the north of the central highlands. Streams, rivers and major pre-colonial irrigation structures. 
are dependent on and linked to the same source of water. What is common to these two examples is a framework of unequal relations within the villages in terms of landownership and control and elite groups forming transvillage networks. No such clear examples of transvillage organisation based on the communities concerned are known from Sri Lankan history.

Against the background of the potential supportive capacity we can compare the village tanks in the study area with some of the large systems of the dry zone. Village tanks from which there are sufficient data on irrigated acreage would have had a capacity to produce $17000-37000 \mathrm{~kg}$ of paddy per year, calculating from a situation before the introduction of high-yielding-varieties (MyrdalRunebjer 1996:155). Further, most of these tanks would not be possible to use each year due to insufficient rain during the maha season. A calculation of the yield from a given tank, for which the field acreage is not known, has to be based on approximation. Knowing

- the water storage capacity of a given tank (from field measurements or from

colonial estimates in relation to reconstruction plans) and

- the water duty in the area ${ }^{1}$

we can obtain an approximate figure for the maximum field acreage. Calculating the yield/ha ${ }^{2}$ with regard to the pre-high-yielding-varieties, and using modern figures suggesting an average consumption per capita of approximately $255 \mathrm{~kg}$ / year or $1400 \mathrm{~kg}$ /"average family" (Stargardt 1998:1723) as necessary from a supportive point of view, we could approach the question of the potential supportive capacity of the different systems. Disregarding the fact that the yield would not be evenly distributed and that the villagers would have had swidden grain as an additional supportive potential, we can note, for comparative purposes only, that - the Kalaväva-Balaluväva would have had the capacity to support 2255 households (or 12400 persons) below the tank,

- the Parakrama Samudra to the east of the study area some 5545 households (or 30500 persons),

- the Sigiri Mahaväva itself approximately 545 households (or 3000 persons), whereas

- the village tank Talkote Pahala väva would have had the capacity to support 21 households (or 116 persons). The latter figure disregards the fact that the tank could not be used each year, and is thus an overestimate of the potential supportive capacity.

\footnotetext{
${ }^{1}$ The local office of the Irrigation Department in Dambulla reckoned with a water duty of 5 -acre feet/acre, which equals $15240 \mathrm{~m} 3 / \mathrm{ha}$, in the Maha season (personal communication $25^{\text {th }}$ September 1992).

${ }^{2}$ The area-specific, low, average pre-high-yielding-varieties figure is used: $577.96-980 \mathrm{~kg} / \mathrm{ha}$ (Ellepola 1947:97).

${ }^{3}$ This estimate is based on figures from rural dry-zone Burma and relates to a family consumption of 1400 $\mathrm{kg} /$ year by a family of 5.5 persons.
} 
The yield-to-seed ratios for the traditional varieties have to be based on figures from other areas. Regarding the parts of Malaysia that have not been influenced by the "Green Revolution", Bray cites figures which indicate a yield-to-seed ratio of 100:1 (Bray 1989[1986]:15) ${ }^{4}$. To put these figures into a context more familiar to the north-west European reader, we can take the Swedish pre-agrarianrevolution figures for yield/ha and yield-to-seed ratios. The average yield-toseed ratio for Sweden during the $14^{\text {th }}$ century has been estimated to be approximately 3:1 (Myrdal 1985:149; see also Bray 1989:15, as regards Europe). The average yield for early $19^{\text {th }}$-century Sweden has been estimated to be $780-900$ $\mathrm{kg} / \mathrm{ha}$ (Hannerberg 1971:79). This is close to the low figures for paddy in the northern part of the dry zone as exemplified above, but with one big difference. The Swedish peasant would have had to set aside one-third, that is some 200-300 $\mathrm{kg}$, for next years' sowing. The Lankan peasant may have had to save only onehundredth for the same purpose.

When calculating man-days required for the construction of irrigation systems, we should note that the societal and economic implications of the volume of work have to be discussed in view of the total time-frame for the construction, as has been pointed out by many scholars (see, e.g., Leach 1959 in relation to Sri Lanka). Most large-scale systems seem to have been the result of several building phases, according to written sources; however, as we do not know these phases from physical evidence but only from written sources, we can not calculate the man-day investment for each stage of work. Calculating only the earth-moving work and relying on modern figures in relation to manual work of this kind, an approximate input would be 1507000 man-days for the Sigiri Mahaväva reservoir with its eastern transbasin canal ${ }^{5}$. This could represent, for example, 1000 persons working for approximately 50 months. If the work was organised in 6-month periods (i.e., excluding the north-west monsoon) the work would thus be completed the ninth year after commencement. From what has been said above, it is clear that it is not possible to speak about irrigated agriculture in general terms but that it is necessary to be specific in time and space.

Something else that has been in focus in discussions of the large-scale systems in Sri Lanka is their abandonment. European travellers and colonial civil servants found them in an abandoned state at least from the $19^{\text {th }}$ century (see below). The causes of "the downfall of the Rajarata civilisation" have been a main theme in the historical research on Sri Lanka (see, e.g., the seminar publication Indrapala ed. 1971 and further references).

Considering the land-use pattern described by the $19^{\text {th }}$-century British, colonial,

\footnotetext{
${ }^{4}$ Figures from Thailand and Cambodia indicate a lower yield-to-seed-ratio of 30:1 to 50:1 (Stargardt 1998:168).

${ }^{5}$ A quarter of a kattiye $(0.708 \mathrm{~m} 3)$ of excavation and carrying was reported to be the daily capacity of the peasants working on the reconstruction of the Kuda Gona väva in the study area (Myrdal-Runebjer 1996: 156$158)$.
} 
civil servants and irrigation engineers, the question is understandable. The irrigation officer Henry Parker described the northern and eastern parts of the dry zone in the late $19^{\text {th }}$ century:

"The food of the Forest Vaeddas consists of fruits, roots of wild yams, and especially honey and the flesh of any animal they can kill, which are chiefly Iguanas, Pigs and Deer. All the Village Vaeddas, and the Tamil speaking Vaeddas (with the exception of a very few who are solely fishermen), and the Wanniyas [Sinhalese or Tamil speaking inhabitants of the northern interior of the Dry Zone] eat the same food, and have in addition the small millet above-mentioned, called Kurahan by the Sinhalese, the Indian Ragi (Eleusine coracana). This is grown in temporary clearings (termed hena by the Sinhalese) made in the forest, all bushes and grass being cut and burnt off, but not the larger trees. After one crop, or sometimes two have been taken off the ground, the clearing is abandoned and allowed to be overgrown once more with jungle, and is not recultivated until five or seven years have elapsed. In their clearings, which are exactly like those of the Sinhalese, are also grown a few red Chillies and Gourds, and sometimes a little Indian Corn, and a small Pulse called Mung (Phaseolus mungo). A very few Village Vaeddas and Wanniyas who live in suitable places for it grow and irrigate a little rice, which the Forest Vaeddas are now learning to cook and eat when they can procure it." (Parker $1981[1909]: 50 \mathrm{ff})$

The epigraphical record mentions what has been interpreted as swidden produce for the first time in the $9^{\text {th }}$ and $10^{\text {th }}$ centuries AD (Gunawardana 1971:15), but Sri Lankan scholars have suggested that swidden cultivation predates irrigated agriculture in Sri Lanka (Gunawardana 1971:15, 1978:259; Perera N.P 1984:455; Siriweera 1986[1983]:68; Siriweera 1990:144).

There was a possible expansion of swidden cultivation over almost the whole island including the wet zone after the decline of large-scale irrigation, as indicated by the Sinhala and Tamil swidden place-names analysed by Michel Gelbert. According to his study, the establishment of swidden place-names did not begin before the $14^{\text {th }}$ century and ended not later than the $18^{\text {th }}$ or early $19^{\text {th }}$ century (Gelbert 1988:38f). In light of the establishment of place-names this could refer to a moving frontier situation, though no chronology of place-name establishment has been presented apart from the overall time frame.

Swidden cultivation as a form of subsistence is mentioned in topographical and social anthropological sources of the $17^{\text {th }}-20^{\text {th }}$ centuries (Myrdal-Runebjer 1994:252-261; Gelbert 1988; Vitebsky 1984; Ryan et al. 1955:158; Baker 1983 [1855]:35; Davy 1983[1821]:201f; Knox 1981[1681]:112-113). The cultivator combined the swidden cultivation of dry grains with the small-scale cultivation of rice in bunded, paddy fields below the village tank from at least the $17^{\text {th }}$ century.

In 1983 the Department of Census and Statistics pointed out that swidden cultivation had expanded throughout the dry zone, and swidden cultivators produced an increasing amount of cash crops (cited in Bryde 1986:105. Regarding 
the increased emphasis on cash crops see also Gelbert 1988:130-139). Cash crops on swidden land that form the basis of cottage industries are, however, also mentioned in the literary sources predating the decline of artificial irrigation in the $13^{\text {th }}$ century: sugar cane, sesame and cotton (Ariyapala 1968:342; Siriweera 1978:43; Siriweera 1990:144).

\section{THE CREATION OF “THE OTHER” - THE ROLE OF ARTIFICIAL IRRIGATION}

In terms of the potential supportive capacity, the man-hours invested in construction and the potential of a centralised control of resources (who is the master of the key to the sluice?), the large-scale irrigation systems are indeed spectacular remains. They, or rather the fact that such structures exist since no field studies of the structures themselves or of rural settlements were carried out in relation to the theory building, have formed the basis of both Euro-centric ideas of "the otherness of the Orient" and of Sri Lankan based history of the times of the ancient kings.

"There have been in Asia, generally, from immemorial times, but three departments of Government: that of Finance, or the plunder of the interior; that of War, or the plunder of the exterior; and, finally, the department of Public Works. Climate and territorial conditions, especially the vast tracts of desert, extending from the Sahara, through Arabia, Persia, India and Tartary, to the most elevated Asiatic highlands, constituted artificial irrigation by canals and waterworks the basis of Oriental agriculture... This prime necessity of an economical and common use of water, which in the Occident, drove private enterprises to voluntary association, as in Flandres and Italy, necessitated in the Orient where civilization was too low and the territorial extent too vast to call into life voluntary association, the interference of the centralizing power of the Government."

The above was written by Karl Marx in the New-York Daily Tribune on June $10^{\text {th }}$ 1853 (Marx 1978[1853]:15), in an article which is in fact a criticism of contemporary British rule in India. Given the Sri Lankan examples above, the description of the causes and of the lack of "voluntary associations" seems far removed from concrete human experience. The centripetal forces and intense rivalry between different groups of landed gentry that are evident in the fully developed largescale irrigation landscape, further modify the role of the "Government" which will be exemplified below (see also Bandaranayake 1984a:11-16). In more recent time Karl Wittfogel used similar arguments in relation to the artificial irrigation in non-European contexts; they formed a basis for his discussion of the political danger involved when colonies gained national independence, and the necessity of private ownership of the basic means of production (Wittfogel 1957). Surprisingly, this latter superficial and ill-founded piece of work has long been treated as a scholarly treatise on the societal implications of artificial irrigation. During the past 30-40 years both South Asian and Western scholars (historians, archaeologists and social anthropologists) have presented results which illustrate that 
the field evidence, material and/or social, does not agree very well with the premises for these theories of development (see e.g., Leach 1959; Thapar 1981; Gunawardana 1971; Adams McC 1981; Butzer 1976; Earle 1978; Glick 1970; Gilman \& Thornes 1985).

Still, the "otherness" characterisation of "the Orient" remains the mainstream basis of descriptions of these societies. In this context it is of interest to note the EU demand that community-funded research should have an "added European value" and lead to "increased European competitiveness" in accordance with the Maastricht and other treaties (see e.g., "A Conference on Research Training in Europe" 1997:76f). ${ }^{6}$

The village-based reclamation work referred to above demonstrates that a different approach - that of documentation of physical entities and social practice - gives possibilities for discussing, not "the other", but the material and social experience and practice in various parts of the world from a comparative point of view. In a Sri Lankan context, the question of water harvesting and control is an essential part of the story.

\section{TECHNIQUES OF ARTIFICIAL IRRIGATION IN THE DRY ZONE OF SRI LANKA}

As a background to the following discussion it is necessary to give a brief introduction to the various structures and techniques used over time for the storage and transport of water in the dry zone of Sri Lanka.

The physical organising factor of the irrigation landscape structure is the obvious fact that water will run downwards; that is, water-saving and transport constructions of any size and any form of complexity will use the force of gravity for their function. The embankment is built above the field; the main sluice outlet is laid

\footnotetext{
${ }^{6}$ The Commission states:

"European civilization has a long history and is very complex. It is today divided between the deep thirst for research and knowledge, the legacy of a tradition which made Europe the first to bring about a technical and industrial revolution and thus change the world, and a deep-seated call for stability and collective security... Being European is to have an advantage of a cultural background of unparalleled variety and depth." (CEC; White Paper on Education and Training 1995:50, 51).

This view is founded on an extremely short time perspective and narrow geographical focus. It is firmly rooted in the colonial tradition. It ignores the development of science and technology that went before the technical and industrial revolution. It ignores the historical research carried out the past thirty years by scholars such as Joseph Needham, Debiprashad Chattopadhyaya, Irfan Habib, Romila Thapar, Janet AbuLughod and others. It fits well with the questions addressed in mainstream research regarding the nonEuropean word. Problematic to any researcher should be that "we" are implicitly contrasted to the different "other" in terms of unspecified aspects of culture and that this is done without knowing "the other". The mainstream focus and research agenda regarding, for example, pre-colonial South Asia has been very different from the type of questions addressed in, for example, Swedish history and prehistory research. Here, that is in Sweden: discussion of rural settlements and production sites parish by parish. There: the whole Indian subcontinent treated as an entity - the north-east Indian $3^{\text {rd }}$ century BC to the $3^{\text {rd }}$ century AD treaty Artashastra, which has been considered possible to use as a source material for describing the north Indian society around the Birth of Christ as well as the extreme south some 1000 years later.
} 
out in the lowest part of the tank, the feeding canal approaching from above the reservoir. The bunded fields are laid out below the embankment, one after the other on sloping ground. This is true for the small village rain-fed tanks as well as for the large reservoirs. The village tanks are often built one above the other forming a chain of tanks, with the fields below and between, called "tank cascades" by Madduma Bandara (ibid 1985). To what extent this involved a planned activity and whether there was co-operation between villages with respect to releasing and distributing water, is not fully clear from the present evidence. The tank at the bottom of the drainage area would have the greatest potential if alone, as the catchment area is larger. With tanks above taking part of the water, it will instead become dependent on the utilisation of water in the fields higher up the catchment area.

Various terms to categorise agricultural techniques in relation to water have been used for the South Asian situation (see e.g., Mencher 1978; Ludden 1985; in relation to archaeological interpretation see Morrison 1995). The cultivation can, for example, be described as wet (perennial availability of water), wet-cumdry (seasonal availability of harvested and stored water where wet or dry crops are grown) or dry (dependent on local precipitation only). The present study is based on data from constructions seen on the present-day surface combined with

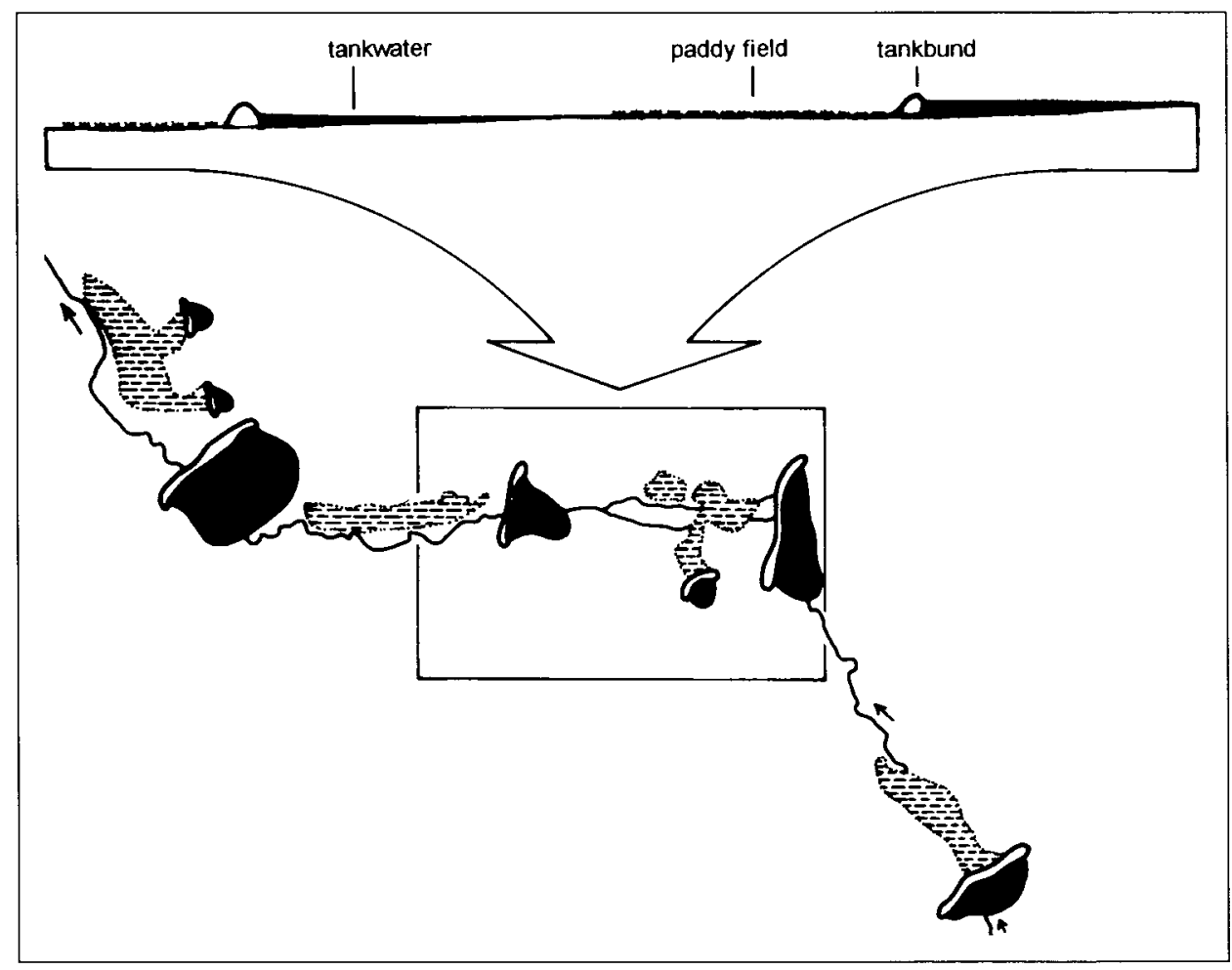

Fig. 4. A tank cascade in plan and profile. An outline diagram. 
documentation of agricultural techniques in the study area. That is, it relates to man-hour input in agrarian structures, and the description takes its starting point from visible structures. The "wet-cum-dry" in this context mainly refers to wet grains on land which in good years are wet enough to support the crop to maturity. What have been observed are

- paddy-fields below reservoirs (certainly wet),

- paddy-fields below rain-fed village tanks (dependent on village-based water harvesting, a wet-cum-dry situation)

- dry grains, vegetables or even wet-rice grown in a small-scale water-harvesting situation below temporary weirs in seasonal creeks and rivers (a less dependable wet-cum-dry situation)

- rain-fed polyculture swidden cultivation. In the Sri Lankan context there is today no ploughing of dry fields, though bunded paddy fields are seen in naturally water-soaked areas. Dry agriculture therefore refers to swidden agriculture.

Water harvesting on a small scale is known from present-day practice and can be assumed to have taken place previously as well, though no physical remains have been dated and the practice is not mentioned in historical sources. Water harvesting on a village-tank-level has been very inadequately studied in terms of time depth of use, though we can assume that the practice predates the largescale constructions for water storage. The transport, storage and management of huge quantities of water are evident from physical remains dating back to the $1^{\text {st }}$ $3^{\text {rd }}$ centuries $A D$ and from present-day practice. Paddy husks from the inner citadel of what later became the capital city of Anuradhapura have been dated to 900600 BC (Deraniyagala 1, 1992:353-366; 2 1992:709f, 715-730), and they represent the earliest known domesticated plants on the island.

The unequal access to resources within the village itself is exemplified in the late $17^{\text {th }}$ century AD. Knox refers to people in the Kandyan kingdom who did not have access to irrigated fields. He states that, "such are fain to sow on dry Land and Till other men's Fields for a subsistence" (Knox 1981:167). The labour requirement of wet-rice cultivation is high. Mencher states in relation to Tamil Nadu, South India, that even the owner of as little as one hectare of paddy field needs some outside help (Mencher 1978:21). Such work is always undertaken in relation to shares of irrigated land with a defined status as to ownership and control. This is in contrast to even the co-operative swidden field where available sources suggest that what is produced is considered to be the property of the persons who invested the labour. This seems to be the case at least from the $12^{\text {th }}$ century AD, when taxes on swidden produce were abolished (Siriweera 1978:44; Myrdal-Runebjer 1996:47).

\section{THE STATE OF THE ART AND ITS IDEOLOGICAL FILTER}

In the study area the landscape was explored from the point of view of labour and technique and of features related to appropriation and control with an attempt 
to anchor each feature in time and space. The lack of basic field research constitutes a problem in this endeavour (Myrdal-Runebjer 1996:49; 74-79), and the historical events during the 500 years of colonial domination constitute a filter, the implications of which have not been studied in the field. A further problem is a lack of interest among historians and archaeologists in the transformation of the Sri Lankan society in the post- $13^{\text {th }}$-century era up to the Portuguese conquest in the $16^{\text {th }}$ century. Sri Lanka of 200 BC to AD 1200 was a society with central places situated in the inland dry zone, which carried a heavy load of monument construction and elite groups not involved in foodproduction on a predominantly agrarian basis. Judging from the little that has been documented, the post- $13^{\text {th }}$-century Sri Lanka saw less of monument construction, a probable demographic shift towards the coastal areas, and an increased importance of oversea trade even before the arrival of the Portuguese (Siriweera 1986:85-94).

A brief description of these latter problems is required as a source-critical background to the results of the fieldwork.

When the then Colonial Secretary of Ceylon, Sir James Emerson Tennent, travelled through the dry zone plains of northern Sri Lanka during the mid-1 $9^{\text {th }}$ century he saw only desolation, a depopulated landscape with huge abandoned constructions for irrigation. He dated this abandonment to the warfare of the $14^{\text {th }}$ century and further stated:

"Thus the process of decay, instead of a gradual decline as in other countries, became sudden and utter desolation in Ceylon." (Tennent 1977[1859]:361f) Some 170 years before this, in the late $17^{\text {th }}$ century, Robert Knox travelled through the same area. Passing the plains around the former capital of Anuradhapura, he stated:

"... a vast great Plain, the like I never saw in all that Island: in the midst whereof is a lake, which may be a mile over, not natural, but made by art, as other Ponds in the Country, to serve them to water their Corn Grounds. This Plain is encompassed round with Woods and small Towns [villages] among them on every side..." (Knox 1981:353)

The large-scale irrigation structures were obviously an important prerequisite for a concentration of population and the production of a surplus to feed non-food producers and enable the construction of elite-related monuments as discussed above. Dysfunction of these structures would have demographic implications.

Apart from Knox's statements, there are indications that some of the large constructions continued to function up to the $17^{\text {th }}$ early $19^{\text {th }}$ century. The Kaudulla tank in the north-eastern part of the dry zone, with a present restored capacity for watering 4272 ha, is reported to have functioned up to AD 1680 (Brohier 1979[1934]:22, Ievers 1899:41,134; Wijesuriya \& Kamaladasa 1988:92). Hurulu väva, north of Sigiriya, with a present restored capacity for watering $3515 \mathrm{ha}$, is said to have been finally breached in 1803-04 (levers 1899:153; Wijesuriya \& Kamaladasa 1988:92). Panda väva in the North-western province, with a water- 
storage capacity of 8.71 million $\mathrm{m} 3$, was finally breached in 1805 (Brohier 1979:4).

The breaching of bunds or deliberate destruction is known from historical sources in various instances since at least the $7^{\text {th }}$ century AD.

"The officers belonging to the retinue of the monarchs on both sides who were established on the frontiers, fought with each other continually. By setting fire to many flourishing villages and market towns, by piercing tanks filled with water, by destroying everywhere the weirs on all the canals and by hewing down all useful trees like the coconut palm and others, they in fighting each other, so devastated the kingdom that it was impossible to trace even the sites of the old villages."

The above is stated in the chronicle "Culavamsa" in relation to the struggle between Vikkamabahu (AD 1111-1132) and the three brothers Kitsirimegha, Sirivallabha and Manabharana (Cvs 61.63-68). Similar statements have been made, for example, with reference to the struggle between Aggabodhi III (AD 628, 629639) and Dathopatissa I (AD 639-650) (Cvs. 44.130-132).

But in contrast to the reconstruction which followed these earlier events, the above-mentioned tanks were left in their abandoned stage. This abandonment seems to have started before the arrival of the Portuguese in the early $16^{\text {th }}$ century. However, Siriweera points out that in contrast to what is stated about the turbulent early $13^{\text {th }}$ century, there are no references to famines during the period from the late $13^{\text {th }}$ to the $16^{\text {th }}$ century (Siriweera 1989:85).

To try to understand the implications of the colonial period in terms of landuse, let us contemplate the arguments for the presence of foreign power and how this power was formed. Most probably it has a bearing on the questions of landuse, and the arguments as such may be a clue to the fact that the colonial impact on land-use has not been seriously studied. There is an ideological filter of which we have to be aware when we use $19^{\text {th }}$-century sources and when we interpret present-day field data.

A thought-provoking text titled "Concerning our rights of possession here" was written by Jan Schreuder, the Dutch Governor of Ceylon from 1757 to 1762.

"For although it may be assumed as a contra-argument that the Kandyans [the inhabitants of the Sri Lankan kingdom in the central highlands], as already stated, did now and then, as at the present time [referring to the uprising 176061], commit hostilities in our territory in violation of our right:

The above exposition of facts is alone sufficient evidence that they can make no pretension with any grounds whatsoever to our territories, and that we, on the contrary have a full right to the Dessavonies of the Three, Four, and Seven Corles, as well as that of Saffregam, the same having been possessed by the Portuguese and devolved upon the Company by right of conquest; and besides this, the contests of this document will also show in its sequel that the activities of the Kandyans were not based so much on any grounds of preten- 
sion but that they were entirely due to their covetous natures or their private interests as well as to desire to vex and embarrass the Company, in order that being successively tired of us as they were of the Portuguese before, they would gladly see us out of the country and remain themselves sole masters thereof. However, the simplest person can easily judge how little all this relates to the matter in hand or can prejudice our rights to our territory." (Schreuder 1946[1762]:9)

But how was this full right achieved? The Portuguese, whose possessions were devolved upon the Company "by right of conquest", arrived with arms in 1517. There followed 100 years of achieving "full right" of possession through "right of conquest". Towards the end, in 1594, Jerome Azavedo was despatched to Ceylon

"to avenge the indignities endured by his fellow-countrymen at the hands of the Kandyan usurper...An internecine war now raged for years in Ceylon, the Portuguese in successive forays penetrating to Kandy, and even Oovah and Saffragam, burning towns, uprooting fruit trees, driving away cattle, and making captives to be enslaved in the lowlands...These conflicts were, however, of uncertain success. On some occasions the invaders, overpowered by the energy of the Kandyans were defeated and put to flight, followed by the exasperated mountaineers to the gates of Colombo. The frontier which separates the maritime districts from the hill country, was the scene of sanguinary conflicts, and at length the low-country Singhalese, roused to desperation by the miseries drawn down on them in never-ending hostilities, and by the atrocities perpetrated by the Portuguese soldiers, manifested a determined resistance to the common oppressors..." (Tennent 1977:564)

In 1597 the "right of possession" was finally achieved for the country apart from the peninsula of Jaffna, the inland dry zone ruled by petty chiefs and the inland state of Kandy. Warfare did not end, however, and the Jaffna peninsula was taken in 1617.

There is an argument for the moral right "to be there" which is common throughout at least the Dutch and British periods of colonial rule and which may be at the very core of ideological legitimisation. The Colonial Secretary James Emerson Tennent (who was himself expelled from office after the rebellion of 1848 ) recounted with regard to the early $19^{\text {th }}$ century when the kingdom of Kandy was still undefeated:

"During this interval, the career of the Kandyan king presents a picture of tyrannous atrocity unsurpassed, if it be even paralleled, in its savage excesses, by any recorded example of human depravity...The forced labour of the people was expended on works of caprice and inutility; and the courtiers who ventured to remonstrate were dismissed and exiled to their estates." (Tennent 1977:615)

The British had a mission to fulfil:

"But the limit of human endurance had been passed: revolt became rife throughout the kingdom: promiscuous executions followed, and the terrified 
nation anxiously watched for the approach of a British force to rescue them from the monster on the throne." (Tennent 1977:617)

Unfortunately the inhabitants did not fully appreciate the result:

"Happy as this consummation [the deposing of the king and the following acceptance of the British occupation] appeared, the tranquillity which ensued was but transient; before two years the same people who had invited the English as deliverers rose in rebellion to expel them as intruders... So impatient had all classes become, that uniformity of feeling supplied the place of organisation and without combination or concert, nearly the whole kingdom rose simultaneously in arms in the autumn of 1817..." (Tennent 1977:618f)

John Davy, an army surgeon and physician, was an eyewitness to the above. While following the army he was able to give us a glimpse of the problematic side of its mission:

"When a district rose in rebellion, one or more military posts were established in it; martial law was proclaimed; the dwellings of the resisting inhabitants were burnt; their fruit trees were often cut down, and the country was scoured in every direction by small detachments, who were authorised to put to death all who made opposition, or were found with arms in their hands. The natives on their part never met us boldly and fairly in the field; they had recourse to stratagems of every kind, and took advantage of the difficult nature of their country, and of their minute knowledge of the ground... Such a system of warfare as this, of which I have partially sketched to outline, had better not be given in detail...For the same reason that I have not entered into details of the warfare, I shall notice only in the most summary manner, the sufferings and miseries inflicted and endured on both sides, whilst the conflict lasted. We suffered most from the harassing nature of the service; from fatigue and privation; and from the effects of these, and of night-marches, and of an unwholesome climate, producing disease. The sufferings of the natives were of a more severe kind and complicated nature. In addition to the horrors of war in its most appalling shape, they had to encounter those of disease, want, and famine, without chance or relief. ... The loss of the natives, killed in the field or executed, or that died of disease and famine, can hardly be calculated; it was, probably, ten times greater than ours, and may have amounted, perhaps to ten thousand.

When one considers this rebellion and its consequences, one almost regrets that we ever entered the Kandyan country. The evils immediately resulting from it, certainly greatly exceed the original benefit we conferred on the natives, in removing a tyrant from the throne." (Davy 1983:246f)

He could, however, console himself with the fact that

"...the rebellion was not the effect of oppression or misrule, but of the innate propensities of the people, concealed till they burst out and showed themselves in acts of violence, that required to be repelled by force." (Davy 1983:247) 
In his "Treating regarding what the Company chiefly has to do here", Schreuder explains to us what has probably been the aim of this energetic input of destruction through the centuries:

"Firstly, to be and remain sole masters of Ceylon to the exclusion of all other nations, and secondly, to see what could be done in all its stations or comptoirs, namely, The collection of the products in particular, and the trade in general." (Schreuder 1946:9)

This implies an interest in how land-use was organised and for what purpose. Following the "right of possession" was the reorganisation of land-use. The coffee plantations in the central highlands, which were part of the background of the 1848 rebellion, and the type and amount of taxes are cases in point. Tennent reflects:

"The Singhalese within the last three hundred years have seen three European nations in succession take possession of their country and monopolise its productions for the enrichment of foreigners. The Portuguese and Dutch extorted its cinnamon and pearls, the British have covered its mountains with plantations of coffee, and its coasts with gardens of coconut palms; but each has failed in turn to inaugurate a policy that would tend successfully to elevate native industry, or emancipate the people themselves from their dependence upon foreigners for food." (Tennent 1977:904)

Having read the above words of the colonial administrators and civil servants on the effects of "rights of conquest", we can now see that from 1517 to 1818 the rural population in various parts of the island was repeatedly subjected to the destruction of their means of subsistence and their dwellings. It may be useful to recall that neither the early colonial impact on demographic patterns nor the British military campaigns up to 1818 has been studied on the basis of the material remains.

The written sources indicate that the early phase of British colonisation was not stable from a demographic point of view. Farmer calls our attention to the remark by Thomas Skinner (Commissioner of Public Works) in 1833 that the population of Nuwarakalawiya (the Anuradhapura region) was rapidly decreasing due to disease and drought (Farmer 1976[1957]:11, citing Skinner, 1891, Fifty Years in Ceylon. London: W.H. Allen). The census record from the northern coastal area around Mannar reports a decrease in population in three out of six decades between 1871 and 1931 (Farmer 1976:12). Thus the migrating, swidden-cultivating and small-scale water-harvesting peasant of the late $19^{\text {th }}$ and the early $20^{\text {th }}$ century, whom we meet in the topographical literature and the administrative accounts, has to be put into the specific historical, turbulent, context of colonial warfare and land-use re-organisation rather than be understood as representing a traditional pattern of land-use. However, the combination of swidden and wet-rice cultivation is indicated in the historical sources of the first millennium AD as seen below. 


\section{PRESENTATION OF THE STUDY AREA}

The following is a description, a close reading of a landscape situated in the northern part of the dry zone plains of Sri Lanka. The fieldwork was conducted 1988-1995 within a Sri Lankan/Swedish settlement-archaeology collaboration project (Bandaranayake et al 1990; Bandaranayake \& Mogren 1994). It was conducted in the region of "Sigiri Bim", which is a Middle Historical period $\left(6^{\text {th }}\right.$ $13^{\text {th }}$ centuries AD) concept referring to the undulating plain surrounding the $5^{\text {th }}$ century AD (short-lived) royal city of Sigiriya and measuring approximately 45 X $35 \mathrm{~km}$. It is situated on the watershed below the central highlands, on land that slopes gently down towards the Indian Ocean and Bay of Bengal to the west and east respectively. Thus it is not situated in the most favourable position from a water-collecting and storage point of view.

Climatically the area is characterised by only one major season of precipitation, the north-east monsoon from mid-October to mid-January. The central highlands form a barrier to the rains of the south-west monsoon. The mean rates of precipitation in the area do not appear to be low: $1680 \mathrm{~mm} /$ year. Half of this amount arrives during the north-east monsoon, while during the driest months of June and July there is an average of only $25 \mathrm{~mm}$ of rain per month. The seasonal character of rainfall is combined with high temperatures (the mean annual temperature is $22.5-25.0$ degrees $C$; in the dry period the mean temperature rises to 27.5 degrees C) and an intensive dry wind ("yalhulanga") blowing during the driest part of the year (de Silva 1988:30f; Perera M.P. 1984:229). This results in a seasonally marked water deficit, where evaporation exceeds rainfall. In Sigiri Bim, during July and August, the vegetation withers, and the small village tanks more or less dry up and even many wells run dry.

There is also a marked yearly variation in precipitation where the north-east monsoon may fail, leaving the cultivator to wait another year before any major rainfall can be expected. The spatial distribution of rain during a given wet season is also highly variable within the area itself. Hence, both agriculture and the possibility of sustaining livestock are closely related to the seasonal constraints of the dry period.

The intensity of rain (when it comes) should also be noted. It causes a heavy run-off and erosion. Much water simply runs to waste unless stored in tanks and reservoirs. Infrequently, devastating cyclones occur, accompanied by torrential rains. This may cause overtopping and rapid erosion and the breaching of earthen tank (here the term for village reservoirs used for agrarian purposes) bunds and reservoirs. In the administrative areas of Anuradhapura and Jaffna Vannis "a great storm" breached almost all the tanks in 1829 (Ievers 1899:136). In 1887180 village tanks were breached (Ievers 1899:158). In the Northern Province in 1897 160 tanks burst (Parker 1981:369f). Several hundreds of canals, anicuts (diversion weirs in rivers) and reservoirs are reported to have burst in the floods of 1947 (Siriweera 1989:81). In the study area the newly restored Peikkulam tank was breached during a similar rainfall in 1978 (Mogren 1990:56). 


\section{ARTIFICIAL IRRIGATION, WATER HARVESTING AND SWIDDEN CULTIVATION IN THE STUDY AREA}

The agrarian landscape in the part of the study area, which is currently not included in the large-scale Mahaveli irrigation project, is dominated by village tanks, one or more in the vicinity of the village. What is described as a traditional organisation; the tank bund with the village beside it and the fields below, is not in evidence everywhere today as villages may incorporate several tanks. Tank bunds are built to dam a run off, a seasonal stream (no natural waterway is perennial in the area).

There are also four major constructions. Two of them are renovated These are Kandalama tank, which is today fed by water from the Mahaveli project (probably initially a $2^{\text {nd }}$-century $\mathrm{AD}$ construction), and Vävala väva, which in its former larger state was once the source of one of the transbasin canals to Sigiri Mahaväva (possibly a $4^{\text {th }}$-century AD construction, see Manatunga 1990:76).

Two of the constructions are abandoned. One is Peikkulam tank, which, from a topographical point of view, competes with the transbasin canal of water from the same source. The tank was renovated in the late $20^{\text {th }}$ century but breached again in 1978 and left (up to at least 1995) in its abandoned state. A $9^{\text {th }}$-century AD pillar inscription was found close to its bund (Ranawella 1984:217), re-granting specified villages to the community of monks at the Abayagiri Mahavihara (in Anuradhapura), but nothing is known about its initial phase of construction. The other, and the largest system, Sigiri Mahaväva, had three supply-canals in its final stage. It also had a long bund in relation to its water storage capacity compared to most other pre-colonial systems, and it had a very narrow catchment area of its own. It is not mentioned in any historical sources, but ${ }^{14} \mathrm{C}$ and stratigraphical evidence date the transbasin system to the post-mid- $5^{\text {th }}$ century and pre- $7^{\text {th }} 8^{\text {th }}$ centuries AD. (Myrdal-Runebjer 1996:128-133). The unfavourable topographical location, the bedrock properties (it is built on a highly weathered limestone band) and the results of the palaeoecological analyses of tankbed sediments all indicate that the transbasin system has not been used, or that it has been used for a short time only (Risberg; Myrdal-Runebjer \& Miller 2002:41). Parts of the construction are now used as village tanks for village-based irrigation that functions independently. From a topographical-functional point of view, these constructions could have been built prior to and independently of the large-scale project.

Within the study area, 223 rain-fed village tanks have been mapped. The date of their construction is not known at present. Some structures are now abandoned. There are indications of re-utilisation of previously abandoned tanks. In A.C. Lawrie's administrative account of 1898 it is stated that out of 22 purana (traditional) villages in Inamaluva Korale (the main part of the study area) three were abandoned, two were explicitly mentioned as not having paddy cultivation. Of 17 villages associated with functioning tanks, only one was said to cultivate paddy every year, whereas 13 were explicitly mentioned as not doing so for lack of water: three "seldom" or "infrequently", one "once in ten years", and nine "once 


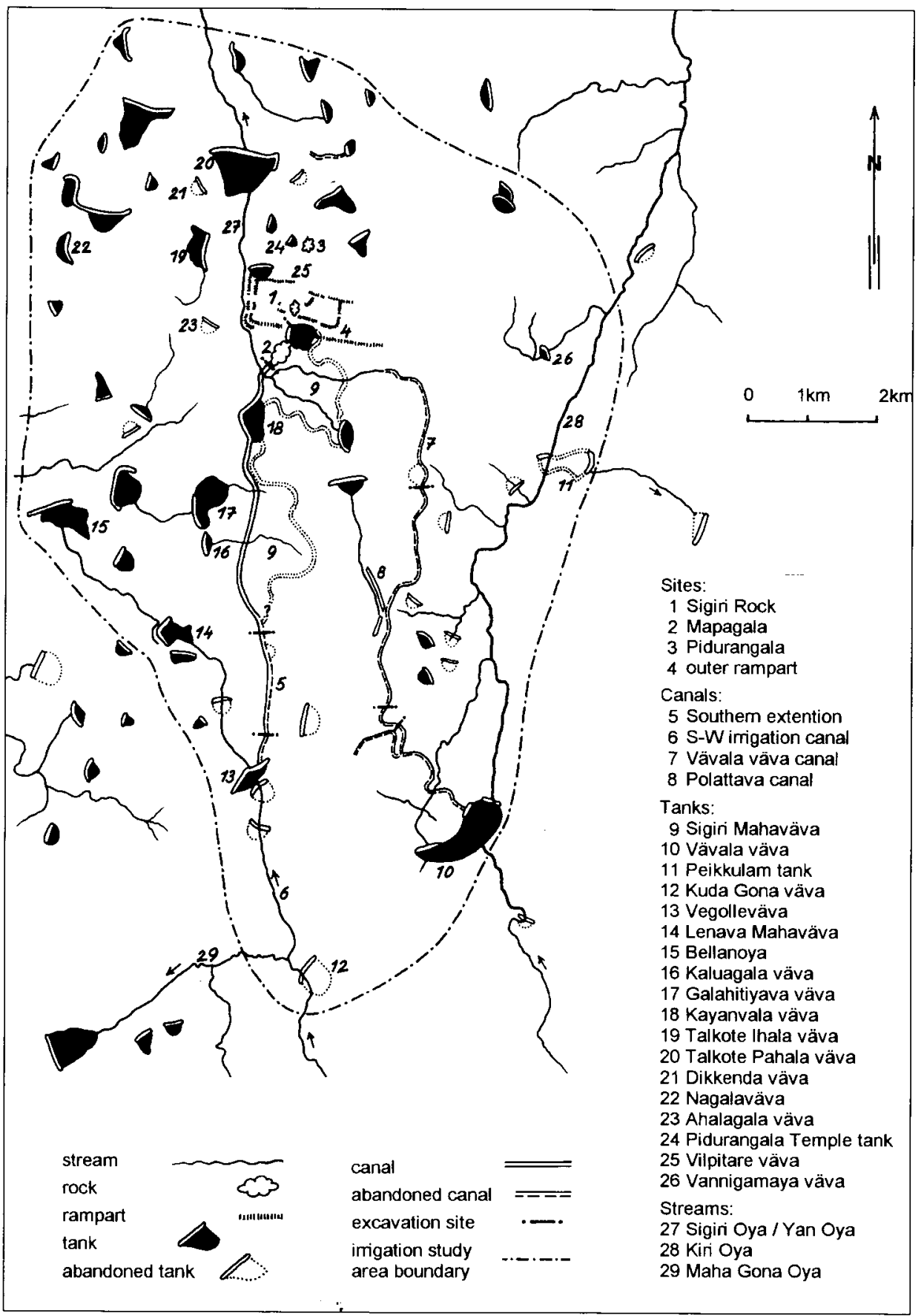

Fig. 5. The abandoned Sigiri Mahaväva in the present village-based irrigation landscape. Excavation sites marked. 
in three or four years". Swidden cultivation is explicitly stated to be the support of two of these nine villages cultivating paddy "once in three or four years" (Lawrie 1988[1896]:169-173).

Paddy is thus not the annual staple crop, but is combined with swidden cultivation. Polyculture swidden is conducted on land belonging to the State. Water harvesting in relation to swidden fields has been observed.

The village tank with the bunded paddy fields below could have been viewed as a stable investment in the landscape. In the field the unstable character (in terms of place) of land-use practices has been observed. These practices may vary between years, and over a longer time period this is even more evident; fallow paddy fields below a tank, paddy fields in a former tank-bed watered by the above lying tank, swidden fields over a former tank bund.

This is the present-day situation, formed by the man-day investments made in the first half of the first millennium, a probable decline, colonial wars, colonial administration and present-day globalisation.

\section{READING THE LANDSCAPE: CONTROL OF RESOURCES IN TIME AND SPACE}

To construct a chronology of land-use and control of resources through time the results of the archaeological field-survey and excavation data have been used. The discussion below focuses on the remains of produce and constructions that are considered to be related to the question of unequal access to raw material resources, land and labour of others, and the statements regarding these features that have been made on durable material.

\section{Statements on stone}

"...even if the twelve great reservoirs are breached, vari (corvée labour) shall not be taken...the Sinhala dues...the Tamil dues shall not be levied" (No E6, E21/E5, Ranawella 1984:203ff).

Written claims to the control of resources (material or personal self) in the study area fall into five different groups (Myrdal-Runebjer 1996:180).

(i) The Early Brahmi inscriptions (300 BC-AD 1) carved on behalf of what might have been a locally based emerging elite ("householder", "village elder", "clan leader" or the sons, daughters, wives or brothers of such persons) and referring to donations of cave dwellings to the Sangha (the Buddhist monastic organisation) or announcing their ownership of such structures. In one instance it is stated that an income goes with the donated cave (No. 857, Paranavitana 1970:66).

(ii) The (few) Early Brahmi inscriptions carved on behalf of (local) rulers with a wider claim to control or referring to such rulers or possibly to royal personages. One such inscription refers to tanks (Somadeva 1990:198f).

(iii) Brahmi rock inscriptions (AD 1-450) in which royal personages are among the donors or in which such personages are referred to by the donor, and when 
shares and revenues from irrigation are also donated to the Sangha.

(iv) The Later Brahmi slab inscriptions (AD 450-650), the majority of which may, according to some scholars, indicate the manumission of individuals from monastic slavery. Other, very different interpretations have been put forward, however (Karunaratne 1984:117f). From this period there is also a "Vaba the brick-layer" who donates seed paddy to an unspecified place (E14, Ranawella 1984:209).

(v) The Brahmi-Sinhala-transition-period pillar and pillar-slab inscriptions (AD 800-1200) carved on behalf of royal personages and announcing donations or re-donations to the Sangha of whole villages, or shares and revenues from irrigation structures and of swidden produce. Grants of immunities to various monastic institutions also date to this period. The King gives the right of labour in specific villages to the Sangha to such an extent that, not even in the event that the "dolos maha vä" (the twelve big reservoirs) burst, would the king order these villagers or the village oxen to help in the reconstruction work. A grant of 23 kalandas of gold is given by one Dalana (without title) in AD 909 to supply the community of monks with cooked rice and curd from named places "regularly till the sun and moon last". People such as the treasurer of Kotagama and the mother of the protector-in-chief join him and donate additional shares (E27, Ranawella 1984:211f).

This former development is in accordance with what is known from other parts of the dry zone during the Late Middle Historic period (Gunawardana 1979:344f; Gunawardana 1982:28f). The rivalry between the king and the Sangha was intense at this time and it seems as if the Sangha was gaining the upper hand in the struggle for power and control of resources. It should be noted that from the $13^{\text {th }}$ century, and probably even earlier, there was a close connection between the secular nobility and the leading members of the Sangha. Stress was laid on youths of "good birth" when selecting adepts to the order. During the time of the Kandyan kingdom at the latest, the Higher Ordination was open only to persons belonging to the landed gentry, and the heads of the most important institutions were recruited from the radala aristocracy (Dewaraja 1988[1972]:164f).

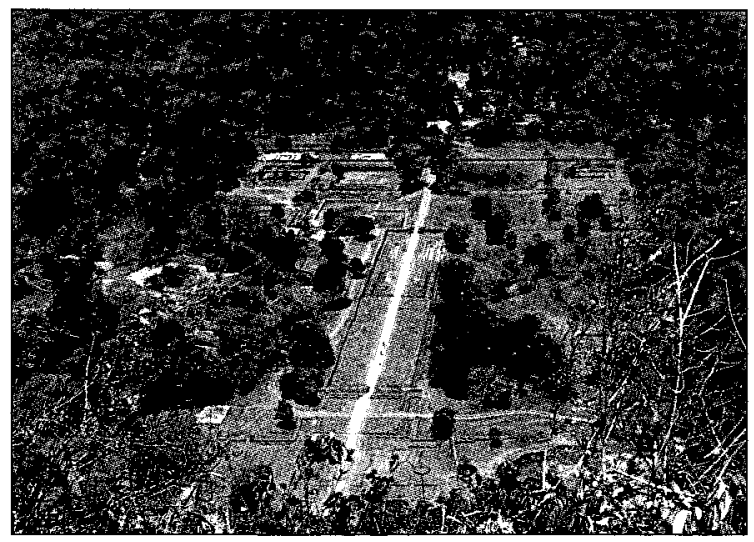

\section{Production}

In the inscriptions of the Early and Middle Historic periods there are references to tanks and tank water. Water taxes are mentioned as having been donated to specified monastic

Fig. 6. The Water Garden of the royal city seen from the palace on top of the Sigiriya rock. Photo by the author. 


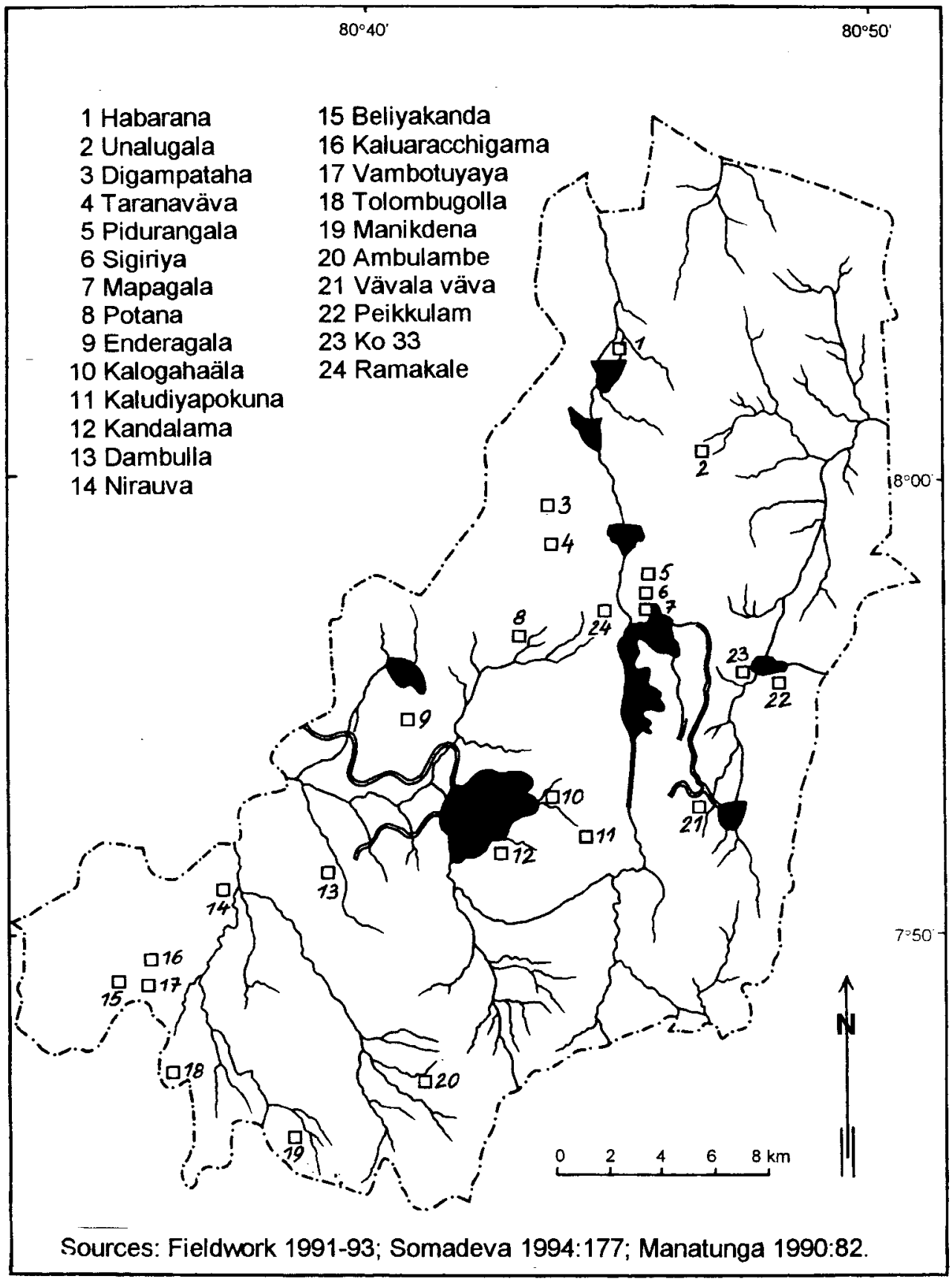

Fig. 7. Inscription sites in the settlement study area. 
institutions, and individual tanks are named. Persons with titles, who have been interpreted as officers connected with the management of irrigation, are among the donors (Paranavitana 1970:65). Somadeva has documented and published one inscription dated by him to the $2^{\text {nd }}$ century $\mathrm{BC}$, which announces donations of taxes levied from at the most six tanks, three of them privately owned (Somadeva 1990:198f). A $4^{\text {th }}$-century AD inscription at the Vävala monastery, in the south-eastern part of the study area, documented and tentatively translated by Manatunga, records the donation of a paddy field and the benefits of taxes from a tank to the monastery (Manatunga 1990:76). Manatunga suggests that the tank referred to is Vävala väva itself.

The Sigiri Mahaväva, which is situated just outside the city wall of the former royal city below the Sigiriya palace, is not mentioned in any inscriptions. ${ }^{14} \mathrm{C}$ datings and stratigraphical evidence have indicated, as mentioned above, a construction phase for the reservoir and its three supply canals to after the mid $-5^{5^{\text {th }}}$ century $\mathrm{AD}$ and before the $7^{\text {th }}-8^{\text {th }}$ centuries $\mathrm{AD}$. Thus it is probably related to the building of the royal city and an attempt to form an agrarian base for a central place in a less than favourable topographical situation.

A section of the bund of the southern supply canal is composed of a natural low ridge running north-south. Here a cultural layer containing potsherds from rice-strainers, large storage jars and other ceramic material was found. One rice grain in an undiagnostic Red-ware potsherd was ${ }^{14} \mathrm{C}$ dated to $174 \mathrm{cal} . \mathrm{BC}$ to 78 cal. AD (2 sigma, Ua-3889, Myrdal-Runebjer 1996:164f). The land on the canalbed side of the ridge now comprises of infrequently used paddy fields and is naturally water soaked in the wet season. It may well have been used during the centuries around the Birth of Christ for rice cultivation in a small-scale waterharvesting situation, as it is today during favourable years.

In the study area we could thus observe indications of water harvesting, of village tanks, of large-scale irrigation systems, as well as evidence of different forms of organisation and control of labour and produce through time.

The development is similar to what is known from other parts of the island. Man-hour investments to increase production were made in the course of time. These were organised within different contexts of power. The most visible were the large-scale structures initiated, extended and repaired from the centuries after the Birth of Christ up to the $13^{\text {th }}$ century $\mathrm{AD}$, often with references to a contemporary king. The king or royal family, other major landowners, trade-related corporations or rich individuals were however, also active with respect to lesser structures (Gunawardana 1982:9ff, 17ff; Gunawardana 1971:24f). The earliest donators; the "householder" and "clan leader", disappear after the inscriptions of the Early Historical period.

Swidden fields are mentioned for the first time in a fragmentary, pillar inscription of AD 899 (second regnal year of Kasyapa IV /AD 898-914/). Here twelve swidden fields, chena, are specified as to geographical location: "...the twelve chenas at Mahavatu in Paludordiga of Amunudora..." (Ranawela 1984:206). 
Another inscription which may refer to swidden tells that the undu (black gram), which is today a typical swidden crop, should be ensured in the track of the fields and be protected in a store-house by "the seven people who come annually to keep accounts" (Ranawella 1984:207). This reference to possible swidden produce mentions what the village should donate to the monks who come to the village for alms; that is, the monks did not only eat rice. The swidden produce, as decentralised and difficult to control as it may seem, was in any case intended to form part of the organised alms-giving during this time. On the basis of epigraphical sources it has been assumed that taxes were levied on swidden produce from the $9^{\text {th }}$ to the $12^{\text {th }}$ century AD (Siriweera 1978:44).

In the study area 33 iron production sites have been identified in the field. Only two sites have been excavated and dated. The earliest dates of iron production have been obtained from the Polwatte/lbbankatuva settlement context of the Proto Historical /Early Historical period (the ${ }^{14} \mathrm{C}$ dates are from the periods $436-226$ $\mathrm{BC}$ and $\mathrm{AD} 347-543$ respectively). Iron production seems to have been conducted during both periods of habitation. The settlement in question yielded evidence of a habitation site for an elite group (Karunaratne 1994:107f). From the $2^{\text {nd }}$ to the $4^{\text {th }}$ century AD iron production had moved out from the small-scale settlement context and was being conducted on a large scale, as seen at the very large, ironproduction site at Dehigaha ela Kanda which was excavated and reported by Forenius and Solangaarachchi. An approximate calculation indicated a production of tens of thousands of tons of iron. A complex technique with a high degree of control of the oxygen supply was in evidence (Forenius \& Solangaarachchi 1994:140). The additional labour processes that were necessary (the cutting of trees and burning of charcoal, for example) indicate a huge man-hour investment in production. Who controlled the raw material, the labour and the products is not known, however. Iron production is not mentioned in any contemporaneous written sources. Iron implements are, of course, important in the dressing of stones for sluice constructions and the quarrying for revetment stones for the inner side of reservoir bunds and as tools in many other spheres of agrarian production and construction work.

In the study area there is only one stone quarry that can not be related to small-scale cutting for domestic purposes in the Late Historical or Modern time. There are cut-marks of wedges in the rock, and there are undressed stone slabs left after splitting or left in the process of being split with wedge-marks in a row (Manatunga 1990:82). Just north of the quarry site there is a badly damaged rock inscription which has been dated on palaeographical evidence to the $6^{\text {th }}-7^{\text {th }}$ centuries (Manatunga 1990:82). Most probably this work was carried out on behalf of others, as stone-slabs or pillars are not known to be part of the rural community architecture.

The production sites for tiles and bricks have not been found (Myrdal-Runebjer 1996:172; 175-176). However, the whole site of the palace and the area inside the city walls contain ruined brick structures, and there is an abundance of tiles 
and bricks as surface material and as fill in every bund and every cultural layer excavated in the vicinity of the palace. It may be possible to calculate the minimum man-hour input for at least the brick production on the basis of the size of remaining structures. These man-hours have been invested for the benefit of others than the producers.

Wheel-made as well as hand-made pottery with a well-made finish was found in the excavation of the Polwatte/Ibbankatuva Proto Historic settlement mentioned above, together with a kiln for pottery production (Karunaratne 1994:108). The area inside the city wall contained pottery both of Sri Lankan and West Asian origin. The production sites for the elite-related Lankan pottery of the $5^{\text {th }}$ century $\mathrm{AD}$ and later have not been identified (Myrdal-Runebjer 1996:175f).

\section{Constructions related to the elite}

The ramparts (10 km long) and moats (close to $8 \mathrm{~km}$ ) surrounding the royal city are part of the overall plan of the palace and gardens (Bandaranayake 1984b:4). Their construction phase thus should be contemporaneous with that of the royal complex itself, that is, the mid- $5^{\text {th }}$ century AD. A cyclopean wall which surrounds the Mapagala rock south of the Sigiriya complex was built in the $5^{\text {th }}$ century $\mathrm{AD}$ (a least the section that was dated) (Kumaradasa 1994:128). A section of the Sigiri Mahaväva bund overlies the southern section of the wall (Myrdal-Runebjer 1996:174). Such constructions are not known to be part of any rural village context, and man-hour input therefore was done on behalf of other persons than the producers. Further, it was done before the Sigiri Mahaväva was built. There is also a "checkpoint" in the form of a collapsed brick structure and stone pillars within a terraced area on the southern side of a narrow pass of the Kondurava range, as well as mortises in the rock on the opposite side of the pass (Manatunga 1990:82). The path leading through the pass connects the Sigiri Bim with the Polonnaruva plain. Tentatively, the initiative to organise the labour processes involved in its construction could be referred to an elite-related interest. This does not necessarily imply an initiative by a head of state, however. The upper Kiri Oya (Milk River) valley where the checkpoint is situated has been considered as an area of refuge for rebellious individuals belonging to the elite in the late Early Historical and Middle Historical periods (Nicholas 1963:111).

Only two secular elite settlements have been identified. One is the Proto Historic/ Early Historic period settlement of Polwatte/lbbankatuva mentioned above. There is a burial ground close to the settlement contemporaneous with the earliest habitation phase. From the Early Historical period at the latest, groups with wide networks and with possibilities of obtaining luxury goods were settled in Sigiri Bim, as shown here by the finds of fine wares and imported pottery, glass artefacts and glass ornaments. The Proto Historical period settlement also contained beads of carnelian and onyx (Karunaratne 1994:107f). Carnelian is not found in Sri Lanka itself and must have been imported, probably from the southern Deccan in India (Seneviratne 1984:276f). 


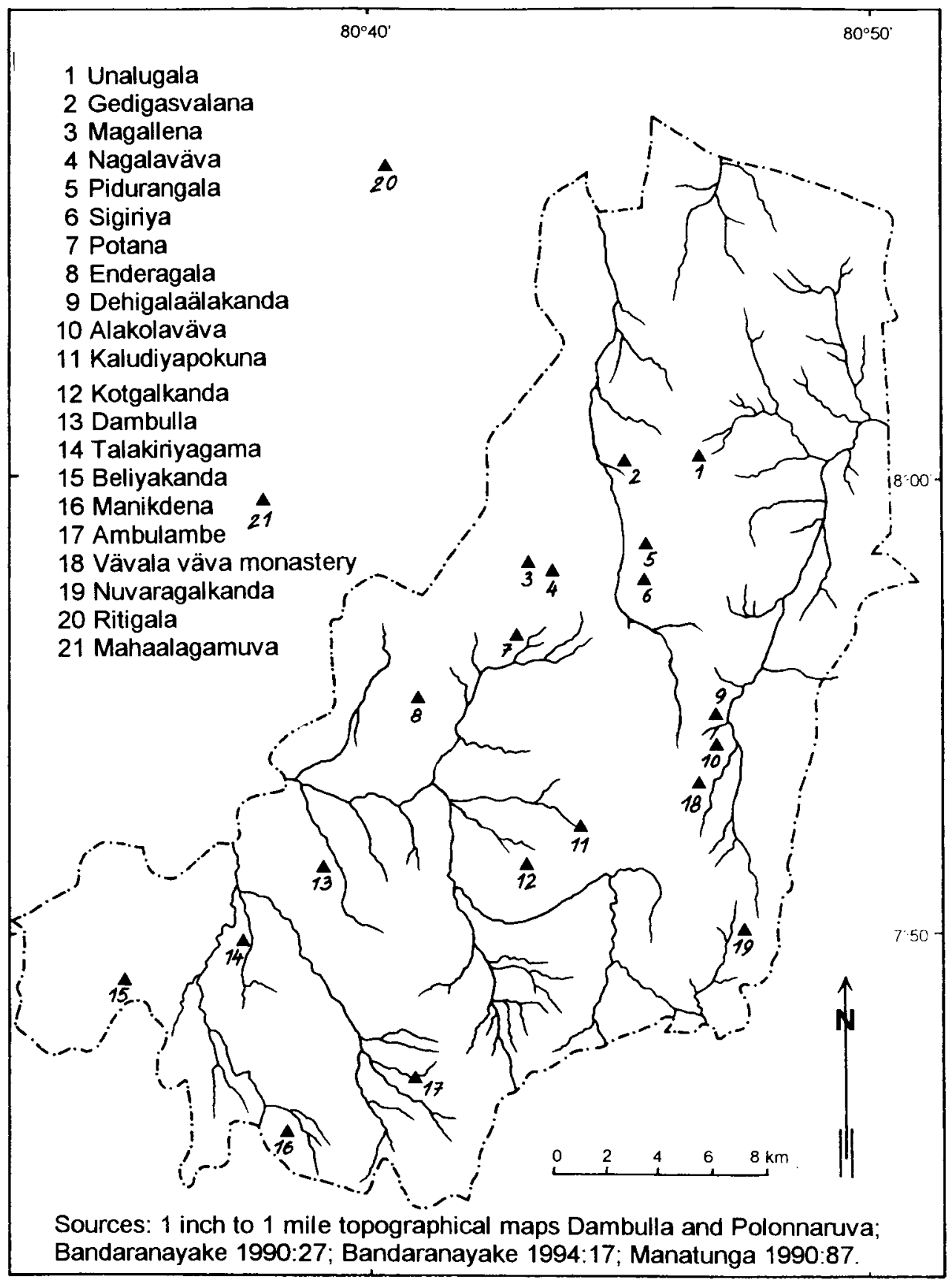

Fig. 8. Early rock-shelter monasteries. 


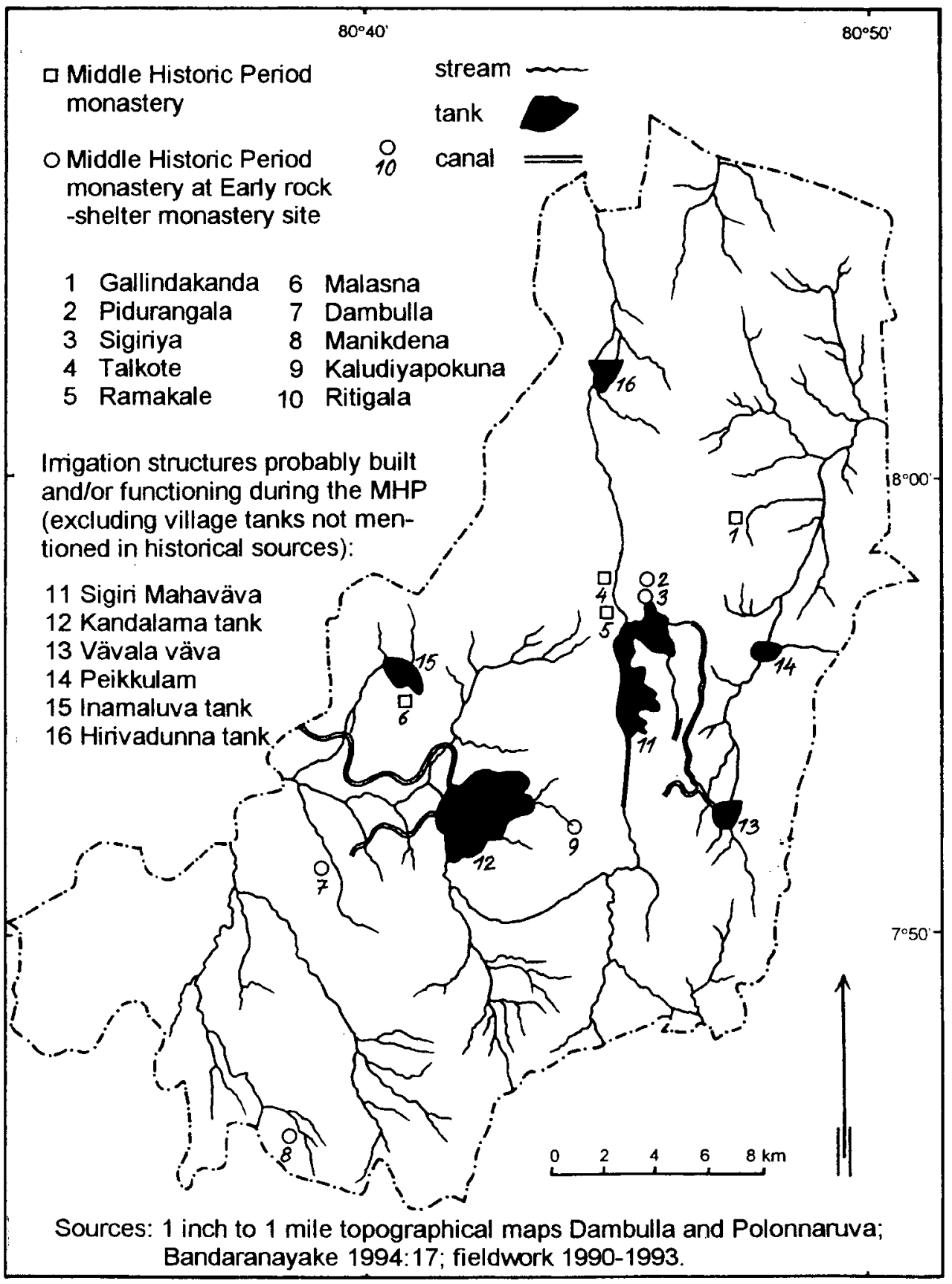

Fig. 9. Middle Historic period monasteries. 
A secular settlement that can surely be associated with an elite that did not invest man-hours in the construction of the buildings, is the $5^{\text {th }}$-century AD Sigiriya royal palace and water gardens. Many types of labour processes have been invested in its construction: lumbering; transport and dressing of timber; burning of tiles and bricks; production of very large iron nails; terracing work; stone cutting, dressing and transport; detailed planning and lay-out of the site; and the construction work itself. Archaeological data seem to corroborate the traditional view of one major building phase: the latter half of the $5^{\text {th }}$ century AD, or more precisely according to historical sources, the 18 years of King Kasyapa's reign between AD 477 and 495 (Bandaranayake 1984b:6; 15).

In the study area there are 26 major monastic sites, constructed between the $2^{\text {nd }}$ century BC and the $10^{\text {th }}$ century AD (Bandaranayake 1994:17; Bandaranayake 1990:23-30). A major construction phase of the free-standing monasteries has been dated between the $5^{\text {th }}$ and the $10^{\text {th }}$ century AD, and some monasteries may be the result of subsequent building phases and thus do not represent a one-time mobilisation of labour (Bandaranayake 1990:23-30). It has been suggested that the large monasteries were inhabited at least up to the first decade of the $10^{\text {th }}$ century AD (Bandaranayake 1990:29). The amount of invested labour increases in the course of time. The early rock-shelter sites with Early Brahmi inscriptions are to a large extent adjustments of natural features, in contrast to the large complexes of free-standing monasteries, such as the Mahanaga Pabatta Vihara and the Pidurangala Vihara. The former complex covers $340000 \mathrm{~m} 2$ and consists of stone-pillared structures and stone-lined terraces, apart from the brick stupa itself (Mogren 1994a:30). The stupa is dated to the $5^{\text {th }}$ century AD on stylistic grounds. The latter complex covers $120000 \mathrm{~m} 2$ (Mogren 1994b:79). Leaving aside the Early Historic period rock-shelters on the Pidurangala rock above, the beginning of the first major phase of construction was the $5^{\text {th }}$ or early $6^{\text {th }}$ century AD (Bandaranayake 1990:23, 28).

\section{CONCLUDING DISCUSSION}

From at least the $7^{\text {th }}$ century to the $19^{\text {th }}$ century AD the written sources indicate that the Lankan peasants had to face the calculated destruction of their means of livelihood time and time again. Their means of survival may well have been the opportunities for small-scale water harvesting and swidden cultivation, within the labour investment possibilities of the family or rural community.

In the study area the archaeological material and the inscriptions of donators show that already from the time of the earliest known tank building there were individuals in a position which enabled them to control the labour of others to some degree. The construction of the Sigiri Mahaväva transbasin irrigation system in the study area can not be explained as a need to increase the production of rice from the perspective of the society at large. It was built in a less than favourable location from a functional point of view and with regard to the availability of water. It may represent an attempt by the then king to increase agrarian production 
(and population) in an area which for a short period of time had become important in another respect; namely as a base of royal power. An intense rivalry among the king, the major landowners and the Sangha (which in turn probably was led by persons recruited from the same social groups) developed during the $9^{\text {th }}$ and $10^{\text {th }}$ centuries.

In other words, water was always part of the agrarian practice, but it could be manipulated in various ways. The demographic implications (amount of people and concentration of habitation) and the possibilities for differentiation and specialisation resulting from the construction of the large irrigation systems, are obvious and can be compared and contrasted to peripheral areas such as the thinly populated and materially poor Sweden prior to the agrarian revolution.

There is, however, no evidence to support the idea that water played an independent role in forming the society of the "East" as compared to the "West", as the $19^{\text {th }}$ and $20^{\text {th }}$ century Euro-centric theories claimed. There is no argument to identify a different "other" when discussing the development of relations among groups of people with different access to resources. There is no evidence, for example, that the control of stored water was invested in an anonymous "Government". Both private and co-operative initiatives were taken, and there was no "classless Government" above an undifferentiated mass of peasants. Kings were recruited from the section of society which controlled land and labour, and in later centuries in intense rivalry with the Sangha, whose leading members in turn came from the same group. The development of the techniques of water storage and water management could be described as the sine qua non for the demographic development (the number of people as well as their ability to live in a concentrated group, and the possibilities of feeding non-food-producers). However, according to the archaeological and early epigraphical record, unequal access to land and labour well predate the period when artificial irrigation was undertaken on a scale that required co-operation on a transvillage level. Thus, the control of water forms an important factor as a base of power for the emerging elite, but it did not have an independent role.

To interpret this development it is necessary to remove the ideological filter, which has ignored the post- $13^{\text {th }}$-century development and made invisible the impact of the colonial powers in reshaping land-use patterns and changing the options for the rural population. The current lack of knowledge should prevent us from interpreting the impoverished, migrating $19^{\text {th }}$-century hunter-gatherer, swidden cultivator of the interior as an "ancient remain".

English revised by Laura Wrang. 


\section{REFERENCES}

Adams, R. McC. 1981. Heartland of cities. Surveys of Ancient Settlement and Land Use on the Central

Floodplain of the Euphrates. Chicago and London.

Abeyratne, M. 1990. Thermoluminiscence in Archaeology. Past Progress and Future Trends in Sri Lanka. Ancient Ceylon. Journal of the Archaeological Survey Department of Sri Lanka. No.11, Vol. 5. Pp. 9-44.

Ariyapala, M. B. 1968. Society in Medieval Ceylon. The state of society in Ceylon as depicted in the Saddharma-ratnavaliya and other literature of the thirteenth century. Colombo.

Baker, S. W. 1983[1855]. Eight years in Ceylon. Dehiwala.

Bandaranayake, S. 1984a. Problems in the classification of the historical societies of the Indian Ocean Region in a taxonomy of social types: a review of the Sri Lankan situation. Paper presented at the $2^{\text {nd }}$ International Conference on Indian Ocean Studies, Perth, December 1984.22 pp.

- 1984b. Part I. Director's report. In: Bandaranayake, S. (Ed). Sigiriya Project. First Archaeological Excavation and Research Report (January-September 1982). Colombo. Pp. 3-23.

- 1990. Approaches to the Settlement Archaeology of the Sigiriya-Dambulla Region. In: Bandaranayake, S.; Epitawatte, S. \& Mogren, M. (Eds). The settlement archaeology of the Sigiriya-Dambulla region. Colombo. Pp. 15-38.

- 1994. Traversing an Archaeological Landscape. In: Bandaranayake, S.; Mogren, M. (Eds). Further studies in the settlement archaeology of the Sigiriya-Dambulla region. Colombo. Pp. 9-20.

Bandaranayake, S., Epitawatte, S \& Mogren, M. (Eds). 1990. The settlement archaeology of the SigiriyaDambulla region. Colombo.

Bandaranayake, S. \& Mogren, M. (Eds). 1994. Further studies in the settlement archaeology of the Sigiriya-Dambulla region. Colombo.

Bray, F. 1989[1986]. The Rice Economies. Technology and Development in Asian Societies. Oxford.

Brohier, R.L. 1979[1934]. Ancient Irrigation Works in Ceylon. Part I. Colombo.

Bryde, J. A. 1986. The Decline in Paddy Cultivation in a Dry Zone village of Sri Lanka. In: Norlund, I. ; Cederroth, S. \& Gerdin, I. (Eds). Rice Societies. Asian Problems and Prospects. Studies on Asian Topics No. 10. Copenhagen. Pp. 81-116.

Butzer, Karl W. 1976. Early hydraulic civilization in Egypt. Chicago.

CEC (Commission of the European Community) 1995. White Paper on Education and Training. COM (95) 590 final, Brussels, 29.11.

Cederroth, Sven. 1995. Managing the Irrigation. Tharu Farmers and the Image of the Common Good. NIAS Reports, No.23. Copenhagen.

Chambers, Robert. 1979. Men and Water: the Organisation and Operation of Irrigation. In: Farmer, B.H. (Ed). Green Revolution? Technology and Change in Rice-growing Areas of Tamil Nadu and Sri Lanka. London. Pp: 340-363.

A Conference on Research Training in Europe. National, Regional and European Experiences. 1997. Snekkersten, Denmark, 29-31 May, 1997. Oslo.

Culavamsa (Cvs). Being the more recent part of Mahavamsa. Part 1,2. 1953. Geiger Wilhelm; Rickmers, C. Mabel. (transl). Colombo.

Davy, J. 1983[1821]. An account of the interior of Ceylon and of its Inhabitants with Travels in that Island. Dehiwala.

Deraniyagala, S. U. 1992. The prehistory of Sri Lanka. An ecological perspective. Memoir vol. 8. Colombo.

Dewaraja, L. S. 1988[1972]. The Kandyan Kingdom of Sri Lanka 1707-1782. Colombo.

Earle, Timothy. 1978. Economic and social organization of a complex chiefdom: the Halelea district, Kaua'i, Hawaii. Ann Arbor, Michigan.

Ellepola, D. B. 1947. Statistical Data of Paddy Production. In: The Engineering Association of Ceylon. Transactions for 1947, Part I. Pp. 77-99.

Farmer, B. H. 1976[1957]. Pioneer Peasant Colonization in Ceylon. A Study in Asian Agrarian Problems. Westport, Connecticut.

Forenius, S ; Rose Solangaarachchi. 1994. Dehigaha-äla-kanda (KO.14) at Alakolaväva: An Early Iron Production Site with a Highly Developed Technology. In: Bandaranayake, S. \& Mogren, M. (Eds). Further studies in the settlement archaeology of the Sigiriya-Dambulla region. Colombo. Pp. 135-142. 
Gelbert, M. 1988. Chena (shifting) cultivation and land transformation in the dry zone of Sri Lanka. Zürich. Gilman, A. \& Thornes, J. B. 1985. Land use and prehistory in south-east Spain. London.

Glick, T. F. 1970. Irrigation and society in medieval Valencia. Cambridge, Massachusetts.

Gunawardana, R.A.L.H. 1971. Irrigation and hydraulic society in early medieval Ceylon. Past and Present. No. 53. Pp. 3-27.

- 1978. Social Function and Political Power: a case study of state formation in irrigation society. The Indian Historical Review Vol.IV, No.2. Pp. 259-273.

- 1979. Robe and Plough. Monasticism and Economic Interest in Early Medieval Sri Lanka. Tucson Arizona.

- (unpublished) 1982. Total power or shared power? A Study of the Hydraulic State and its Transformations in Sri Lanka from the Third to the Ninth Century A.D. Seminar for Asian Studies. Discussion Paper No.4. Peradeniya University. 34 pp.

Hannerberg, D. 1971. Svenskt agrarsamhälle under 1200 år. Gård och åker. Skörd och boskap. Stockholm, Göteborg, Lund.

Ievers, R. W. 1899. Manual of the North-Central Province, Ceylon. Colombo.

Indrapala, K. (Ed.) 1971. The Collapse of the Rajarata Civilization in Ceylon and the Drift to the Southwest. Ceylon Study Seminar. Peradeniya.

Karunaratne, P. 1994. A Brief Report of the Excavation at Ibbankatuva, a Proto and Early Historic Settlement Site. In: Bandaranayake, S. \& Mogren, M. (Eds). Further studies in the settlement archaeology of the Sigiriya-Dambulla region. Colombo. Pp. 105-110.

Karunaratne, S. (Ed). 1984. Epigraphical Zeylanica. Special Volume VII. The Brahmi inscriptions of Sri Lanka. Colombo.

Knox, Robert. 1981[1681]. An historical relation of Ceylon. Dehiwala.

Kumaradasa, W.A. 1994. New Information on Mapagala. In: Bandaranayake, S. \& Mogren, M. (Eds). Further studies in the settlement archaeology of the Sigiriya-Dambulla region. Colombo. Pp. 113-131.

Lawrie, Archibald, Campbell. 1988[1896]. A Gazetteer of the Central Province of Ceylon. Vol I,II. Colombo.

Leach, E.R. 1959. Hydraulic society in Ceylon. Past and Present. No.15. Pp. 2-26.

Ludden, D. 1985. Peasant History in South India. New Jersey.

Madduma Bandara, C.M. 1985. Catchment Ecosystems and Village Tank Cascades in the Dry Zone of Sri Lanka: a study of the Mahapotana Korale in the North Central Province. In: Yoshino, M.M.; Kayane, I. \& Madduma Bandara, C.M. (Eds). Climate, water and agriculture in Sri Lanka. Ibakari. Pp. 61-76.

Manatunga, A. 1990. The Kiri Oya valley. In: Bandaranayake, S.; Epitawatte, S. \&. Mogren, M. (Eds). The settlement archaeology of the Sigiriya-Dambulla region. Colombo. Pp. 73-92.

Marx, K. 1978[1853]. The British rule in India. The New York Daily Tribune. No. 3804, June 25, 1853. In: Marx, Engels. The First Indian War of Independence 1857-1859. Moscow. Pp. 13-19.

Mencher, J.P. 1978. Agriculture and Social Structure in Tamil Nadu. Durham.

Mogren, M. 1990. Project strategies: methodology and perspectives. In: Bandaranayake, S.; Epitawatte S. \& Mogren, M (Eds). The settlement archaeology of the Sigiriya-Dambulla region. Colombo. Pp. 49-60.

- 1994a. Objectives, Methods, Constraints and Perspectives. In: Bandaranayake, S. \& Mogren, M (Eds). Further studies in the settlement archaeology of the Sigiriya-Dambulla region. Colombo. Pp. 23-36.

- 1994b. The archaeology of Talkote. In: Bandaranayake, S. \& Mogren, M. Further studies in the settlement archaeology of the Sigiriva-Dambulla region. (Eds). Colombo. Pp. 71-89.

Morrison, K. D. 1995. Fields of Victory: Vijayanagara and the Course of Intensification. New Delhi.

Myrdal, J. 1985. Medeltidens åkerbruk. Agrarteknik i Sverige ca 1000 till 1520. Nordiska museets Handlingar 105. Stockholm.

Myrdal-Runebjer, E. 1994. Food procurement: labour processes and environmental setting. In: Bandaranayake, S. \& Mogren, M. (Eds). Further studies in the settlement archaeology of the Sigiriya-Dambulla region. Colombo. Pp. 241-262.

- 1996. Rice and Millet. An archaeological case study of a Sri Lankan transbasin irrigation system. GOTARC. Series B. Gothenburg Archaeological Theses. No. 6. Göteborg university. Department of Archaeology. 
Nicholas, C.W. 1963. Historical topography of ancient and medieval Ceylon. Journal of the Ceylon Branch of the Royal Asiatic Society. New Series, Vol. VI, Special Number.

- 1973[1955]. The irrigation works of King Parakkamabahu I. In: Saparamadu, S.D. (Ed). The Polonnaruva

Period. The Ceylon Historical Journal Vol. 4. Dehiwala. Pp. 58-76.

Paranavitana, S. 1970. Inscriptions of Ceylon. Vol 1. Colombo.

Parker, H. 1981 [1909]. Ancient Ceylon. New Delhi.

Perera M. P. 1984. The plain of Sigiriya in its geographical setting. In: Bandaranayake, S. (Ed). Sigiriya Project. First Archaeological Excavation and Research Report (January-September 1982). Colombo. Pp. 228-230.

Perera N. P 1984. Natural resources, settlements and land use. In: Fernando, C.H. (Ed). Ecology and Biogeography in Sri Lanka. The Hague. Pp. 453-492.

Ranawella, S. 1984. Epigraphy. In: Bandaranayake, S. (Ed). Sigiriya Project. First Archaeological Excavation and Research Report (January-September 1982). Colombo. Pp. 198-218.

Risberg, J., Myrdal-Runebjer, E. \& Miller, U. 2002. Sediment and soil characteristics and an evaluation of their applicability to the irrigation history in Sigiriya, Sri Lanka. Journal of Nordic Archaeological Science. Vol. 13. Pp. $27-42$

Ryan, B., Arulpragasam, C. \& Bibile, C. 1955. The agricultural system of a Ceylon jungle village. Eastern Anthropologist. Vol. 8. Nos 3-4. Pp. 151-159.

Schreuder, Jan. 1946[1762]. Memoir of Jan Schreuder, Governor of Ceylon. Selections from the Dutch Records of the Ceylon Government. No. 5. Colombo.

Seneviratne, Sudharshan. 1984. The Archaeology of the Megalithic - Black and Red Ware Complex in Sri Lanka. Ancient Ceylon. No. 5. Pp. 237-307.

de Silva, M. B. G. 1988. Temperature. In: Somasekaram, T.; de Silva, M.B.G; Perera, L.A.G; Karunanayake, M.M.; Perera, M.P. \& Epitawatte, D.S. (Eds). The National Atlas of Sri Lanka. Survey Department. Pp. 30-37.

Siriweera, W. 1. 1978. Agriculture in medieval Sri Lanka. The Ceylon Historical Journal. Vol. 25, Nos. 14. Pp. 34-50.

- 1986[1983]. Land use and demographic shifts in Ancient Sri Lanka. The Sri Lanka Journal of the Humanities. 1983. Vol. 9. Nos. 1-2. Pp. 67-94.

- 1989. Floods, Droughts and Famines in Pre-Colonial Sri Lanka. Special Issue. Modern Sri Lanka Studies. K.W. Goonewardena Felicitation Volume. Vol. 2, 1987. de Silva, C.R. \& Kiribamune, Sirima (Eds). Peradeniya. Pp. 79-88.

- 1990. Farming systems in the ancient Dry Zone. In: Bandaranayake, S.; Epitawatte, S. \& Mogren, M. (Eds). The settlement archaeology of the Sigiriya-Dambulla region. Colombo. Pp. 141-148.

Somadeva, R. 1990. The Beliyakanda, Kaluarachchigama and Neeravva stone inscriptions. In: Bandaranayake, S.; Epitawatte, S \& Mogren, M. (Eds)The settlement archaeology of the Sigiriya-Dambulla region. Colombo. Pp. 195-200.

Stargardt, J. 1998. Earth, Rice, Water; 'Reading the Landscape' as a Record of the History of Satingpra, South Thailand. In: Grove, R.H.; Damodaran, V. \& Sangwan, S. (Eds). Nature and the Orient. The Environmental History of South and Southeast Asia. Delhi, Calcutta, Chennai, Mumbai. Pp. 127-183.

Tennent, Sir J. Emerson. 1977[1859]. Ceylon. An account of the Island Physical, Historical and Topographical with Notices of its Natural History, Antiquities and Productions. Vol. 1\&2. Dehiwala.

Thapar, R. 1981. Ideology and the interpretation of early Indian history. Social Science Information. SAGE. London and Beverly Hills. Vol. 20, No. 2. Pp. 239-258.

Wijesuriya, L.T. \& Kamaladasa, G.B.U. 1988. Irrigation schemes. In: Somasekaram, T.; de Silva, M.B.G; Perera, L.A.G.; Karunanayake, M.M.; Perera, M.P. \& Epitawatte, D.S. (Eds). The National Atlas of Sri Lanka. Survey Department. Pp. 92-93.

Vitebsky, P. 1984. Policy dilemmas for unirrigated agriculture in southeastern Sri Lanka: a social anthropologist's report on shifting and semi-permanent cultivation in an area of Moneragala District. University of Cambridge.

Wittfogel, K. A. 1957. Oriental Despotism: a Comparative Study of Total Power: New Haven. 